\title{
An Evaluation of Getting the Message: A Reading Course for Schools-Based on Reading Theories
}

\author{
Qiudong Li \\ Department of English Language and Linguistics, Foshan Open University, Foshan, China \\ Email: 1295456759@qq.com
}

How to cite this paper: Li, Q.D. (2021) An Evaluation of Getting the Message: A Reading Course for Schools-Based on Reading Theories. Open Access Library Journal, 8: e7269.

https://doi.org/10.4236/oalib.1107269

Received: February 25, 2021

Accepted: March 19, 2021

Published: March 22, 2021

Copyright $\odot 2021$ by author(s) and Open Access Library Inc.

This work is licensed under the Creative Commons Attribution International License (CC BY 4.0).

http://creativecommons.org/licenses/by/4.0/

\section{(c) (i) Open Access}

\begin{abstract}
In the context of English as a foreign language (EFL), English textbooks are one of the most common and valuable materials to develop learners' reading ability. So it is imperative for teachers to evaluate whether or not a textbook is helpful for learners to improve their reading comprehension. This study attempts to analyze Getting the Message: A Reading Course for Schools (Student's Book One), a widely used reading material for junior middle school students, from the perspectives of schema theory, reading strategies, motivation, and vocabulary growth and grammar, all of which are believed to exert a significant effect on learners' development of English reading proficiency. Furthermore, the strengths and weaknesses of this textbook are discussed. English teachers especially those who teach reading to EFL learners and English language teaching (ELT) materials developers will find this course book enlightening when selecting an appropriate intensive and extensive reading textbook.
\end{abstract}

\section{Subject Areas}

English Language Teaching, Linguistics

\section{Keywords}

ELT Materials Evaluation, Getting the Message, Textbooks for Intensive Reading, Reading Theories, Extensive Reading

\section{Introduction}

There is no doubt that excellent English textbooks, to a great extent, play a crucial role in developing learners' reading ability. For one thing, they provide students with abundant English input. For another thing, teachers largely rely on them to practise English instruction in the classroom. However, not all reading 
textbooks can be able to fulfill the purposes of students and teachers. Textbook users particularly teachers should therefore have to carefully scrutinize the textbooks that they are using or will use. This study attempts to investigate the widely used textbook titled Getting the Message: A Reading Course for Schools (Student's Book One) on a basis of reading theories in English language teaching. For this aim, it begins with providing a comprehensive overview of the textbook in terms of topics, text types, and reading strategies that each unit covers. Then the main focus of the paper will be placed upon how to evaluate the textbook based on reading theories. Finally, it ends with a conclusion as well as the limitation of the study and the potential directions for future research.

\section{Description of the Textbook}

Authored by Murphy and Janelle and published by Cambridge University Press in 1995, Getting the Message is a coursebook series composed of Student's Book One, Book Two, and Book Three, which mainly targets EFL middle school students of 11 to 16 years old from elementary to intermediate level. As such, Student's Book One is eminently suitable for junior middle school students and is specially designed to develop their intensive reading skills as well as vocabulary, grammar, and text type knowledge. Further to this, it can serve as a supplementary resource for students' extensive reading.

Getting the Message: A Reading Course for Schools (Student's Book One) consists of ten units, each of which touches on one or two interesting topics, text types, and reading strategies. As is shown in Table 1, the topics of each unit are closely related to teenagers' life, and a range of text types includes letters, magazines, comic strips, reports, and so on. More importantly, almost each unit has at least one specific teaching goal of developing students' reading strategies to facilitate their reading comprehension, and these strategies are incorporated into pre-, whilst- and post-reading activities. Specifically speaking, learners' prior knowledge about topics and text types is activated in pre-reading activities so as to make preparations for reading. While reading for the first time, they need to answer five questions about the main idea of the passage; and then they read again to deal with specific details of the passage. In post-reading exercises, vocabulary, grammar, and text organization are highlighted. At the end of each unit, there is a section "Developing skills" which encourages students to discuss and summarize their reading skills gained. Finally, adding to the textbook's charm is the supplementary audio-cassette, in which the recordings will assist students in improving their listening.

\section{Analysis and Discussion}

In this section, the textbook is evaluated from the perspective of reading theories. It is found that four major factors which influence students' reading comprehension permeate Getting the message. Then its strengths and weaknesses are discussed as well. 
Table 1. An overview of Book One.

\begin{tabular}{lccc}
\hline \multicolumn{1}{c}{ Units } & Topics & Text Types & Reading Strategies \\
\hline 1) A new game & ball games, Hocker & letter, rules & reading for specific information \\
picture story, & newspaper article & $\begin{array}{c}\text { using titles, pictures, headlines } \\
\text { to predict }\end{array}$ \\
2) What do you want to do with money? & honesty, reward & magazine article & reading speed \\
3) Ghosts, grub and adventure & planning a trip & short story & reading for gist \\
4) Lucky to be alive & adventure at sea & magazine article & predicting, reading speed \\
5) Who made it first? Inventors and inventions. & inventions & narrative report & predicting, guessing the meaning \\
of new words, summarizing
\end{tabular}

Source: Murphy, D. and Janelle, C. (1995, pp. 4-5) Getting the Message: A Reading Course for Schools (Student's Book One). Cambridge University Press, Cambridge [1].

\subsection{Schema Theory in Reading Comprehension}

Schema, i.e., prior or background knowledge, is generally categorized into content schema and formal schema: the former is about readers' topical and cultural background knowledge, while the latter involves the knowledge of text organization in different genres (Carrell \& Eisterhold, 1983) [2]. According to schema theory, the more familiar with schemata readers are, the more facilitative they will become for readers' reading comprehension. But the condition is that readers should reach a threshold level of the target language.

In this textbook, the materials writers design two types of lead-in activities to help readers create their schemata prior to reading. Activity 1 aims to elicit students' relevant ideas to the passage topic and activate their content schema. For instance, Unit 1 introduces a new ball game called "Hocker". Such questions as Do you play any ball games? Are you in a team? How many people are there in your team? are posed to help students to recall what they have known about this game. On the other hand, Activity 2 attempts to raise students' awareness of genre knowledge by asking them to notice titles or subtitles, pictures, figures of the passages. As an example, the passage in Unit 3, a newspaper article, requires students to examine the title, headings, and illustrations to predict text contents.

In a cognitive sense, top-down processing model of reading is reflected in these two pre-reading activities. In other words, readers will use their background knowledge to facilitate inferencing before word recognition and syntactic parsing begin. This higher-level reading process has been evidenced by many empirical studies e.g. (Alptekin, 2006 [3]; Hudson, 2007 [4]; Sharp, 2004 [5]). But in this textbook, there are some unfamiliar topics that may pose challenges for middle school students in terms of cognitive level and living surroundings, 
like Space Travel in Unit 7 and Wet Rice Growing in Unit 10. As a result, teachers should introduce some technical terms on space to students so that they have a fundamental background knowledge. Likewise, for those who do not reside in the countryside and know little about growing rice, teachers can play a video of planting rice to help them create a schema.

\subsection{Training of Reading Strategies in the Classroom}

A strategy may be defined as "a conscious procedure carried out to solve problems in the comprehension process" (Pang, 2001, p. 6) [6], which is often divided into cognitive strategies, i.e., various methods and techniques adopted by learners to construct meaning, and metacognitive strategies that are used consciously to plan, control, monitor, evaluate, and summarize those cognitive strategies. According to Grabe (2009) [7], these two kinds of strategies are not absolutely exclusive from each other, but rather complementary. Actually, both L1 and L2 reading are concerned with a strategic process. Numerous empirical studies have identified a large number of cognitive and metacognitive strategies and shown that successful readers excel at using strategies to achieve comprehension to the greatest extent (e.g., Cohen, 1984 [8]; Griffiths, 2013 [9]; O’Malley \& Chamot, 1990 [10]; Oxford, 1990 [11]).

As can be seen in Table 1, this textbook requires students to master the following reading strategies: predicting, reading for gist and specific information, guessing word meaning from context, and using schema knowledge, to name a few. Obviously, it is believed that if teachers incorporate reading strategies into formal instruction in the classroom, students will display more effective comprehension and become a strategic reader (Chamot, 2005) [12]. In Activity 7 “Developing skills", students' attention is shifted to reading strategies. For example, in Unit 6 some questions are put forward for students to discuss- "Did you use the illustrations a) to help you predict what the text was about, and b) to help you guess the meaning of new words?" (Murphy \& Janelle, 1995, p. 29) [1].

These discussion questions aim to develop students' predicting and lexical inferencing strategies. However, if I were the teacher, I would give young students a verbal modelling in $\mathrm{L} 1$ at the beginning of class so that they could understand how to correctly apply the strategies to reading, and then ask them to reflect on reading strategies to develop their critical literacy. In this way, it would be more efficient for junior middle school students to acquire reading skills.

\subsection{The Role of Motivation in Reading}

Motivation, simply interpreted as a drive or an impetus to do something, plays a significant part in language learning. Higher motivation tends to promote more successful learning. The motivation in reading is no exception and it can be influenced by many factors, such as teachers' teaching style or methods, text contents, tasks, and so forth. Therefore, readers' motivation should be maintained and enhanced in reading a good English textbook. 
First of all, Getting the Message: A Reading Course for Schools (Student's Book One) has selected a wide range of interesting passages to cater to middle school students. The topics range from sports (Unit 1 and Unit 8), travel and adventure (Unit 3, Unit 4, Unit 6, and Unit 9) to science and technology (Unit 5 and Unit 7), personal relationships (Unit 2), and geography (Unit 10). All the topics are quite tailor-made for teenagers. Furthermore, the reading materials are of different text types, including letters, dialogues, newspapers and magazine articles, narration reports, etc. In terms of length, every text contains 400 to 500 words on average. In brief, an array of readable authentic texts and genres truly reflects the principle of reading for pleasure.

Second, students' motivation to read can be increased "when the reading tasks and activities are relevant to their lives" (Gambrell, 2011, p. 173) [13], because they will engage them more in something associated with their personal events. For example, Activity 6 "The topic and you" is one way of linking readers' personal experiences and texts. In this activity, students are assigned a role to write something like game rules, a short letter, a note, a story, and the like. The writing tasks are largely an individual work in which writers can express their personal opinions or ideas. Sometimes the activity offers an opportunity for students to choose from two subtasks according to their own preference, like in Unit 10:

1) What do you know about farming in your country? Write about either growing a crop or raising farm animals for a book on geography.

2) How do you look after a pet animal such as a cat or a dog? Write a short article for your school magazine about what you have to do to keep them healthy. (Murphy \& Janelle, 1995, p. 45) [1].

Moreover, the writing tasks have no word limits. As a result, low-proficiency students will not regard writing as a burdensome task any more, while highproficiency students will feel inspired to write as much as possible. Therefore, this kind of activity is very motivating for students.

\subsection{The Vocabulary Growth and Grammar in Reading Process}

Vocabulary and grammar in reading process are the most basic language factors which influence reading comprehension. In order to become a fluent reader, students have to be automatic in word recognition and syntactic parsing. Hence, middle school students at the threshold language level need to increase their English vocabulary size and enrich grammatical knowledge.

Each unit contains lots of exercises about English words and grammar. Table 2 outlines the language focuses of Student's Book One. Like most EFL textbooks for middle school students, Getting the Message also highlights the teaching of core vocabulary and grammatical knowledge, like countable and uncountable nouns, pronouns, adjectives ending with -ed and -ing, irregular verbs, etc. What makes the textbook distinctive from others is that it presents some important vocabulary learning strategies, including grouping word families of the same kind, using a dictionary, guessing the meaning of new words, and word formation 
Table 2. Language focuses of Book One.

\begin{tabular}{|c|c|}
\hline Units & Vocabulary and Grammatical Points \\
\hline 1) A new game & $\begin{array}{l}\text { You can..., } \text { but you can't..., suffix: -ball, } \\
\text { recording words }\end{array}$ \\
\hline 2) What do you want to do with money? & irregular verbs, prepositions, recording words \\
\hline 3) Ghosts, grub and adventure & $\begin{array}{l}\text { words for food and containers, quantifiers, } \\
\text { countable \& uncountable nouns, pronouns }\end{array}$ \\
\hline 4) Lucky to be alive & $\begin{array}{c}\text { comparatives, word families of adj. \& } \mathrm{n} . \\
\text { using a dictionary }\end{array}$ \\
\hline 5) Who made it first? Inventors and inventions. & word families of v. \& n., compounds \\
\hline 6) The report of a young adventurer & $\begin{array}{l}\text { adjectives (-ed, }- \text { ing), guessing the meaning } \\
\text { of new words, recording words }\end{array}$ \\
\hline 7) Space travel & pronouns (it, they, this, these) \\
\hline 8) Sports reports & word families of sports \& people \\
\hline 9) We're organizing a rescue. & $\begin{array}{l}\text { possessive pronouns (mine, ours, etc.), } \\
\text { word families of weather }\end{array}$ \\
\hline 10) Farming & pronouns, synonyms, linking words \\
\hline
\end{tabular}

Source: Murphy, D. and Janelle, C. (1995, pp. 4-5) Getting the Message: A Reading Course for Schools (Student's Book One). Cambridge University Press, Cambridge [1].

(e.g., suffixes and compounds). Besides, students are encouraged to record new words in their own vocabulary notebooks. In my opinion, this is a very effective way of memorizing vocabulary. First, it calls for readers' attention and autonomy to write down new words. Second, they can review the recorded words regularly in case they forget (Laufer, Meara, \& Nation, 2005) [14].

Unfortunately, despite the emphasis on some vocabulary learning strategies, a glossary of new words and expressions in the passages is not compiled. Consequently, teachers and students do not know which words should be given priority to.

\subsection{Strengths and Weaknesses of the Textbook}

Based upon the theories and principles of reading pedagogy, Getting the Message: A Reading Course for Schools (Student's Book One), by and large, proves to be highly valuable for middle school teachers and students. Pedagogically speaking, this textbook has several strengths.

First and foremost, the activities before, during and after reading accomplish different reading purposes. Before reading, Activity 1 and Activity 2 activate readers' background knowledge. During reading, readers read for gist by skimming the passage in Activity 3, and then read for specific information by scanning the passage in Activity 4. After reading, Activity 5 offers readers with new vocabulary and grammar exercises. Activity 6 aims to provide students an opportunity to produce extended output by recycling key vocabulary and struc- 
tures from the source texts. This way of designing tasks verifies that reading is a purposeful process. With regard to interaction pattern, individual work, pair work, and group work are interwoven together to make the activities more fascinating.

Next, the reading materials are authentic. Compared with some English textbooks published elsewhere in the world which are featured by lengthy texts without any attractive illustrations, every passage in this textbook is illustrated with many real-life pictures. In addition, all the characters appearing in this book use genuine English names so that students can experience the authenticity of the target culture.

However, since it is originally intended for an intensive reading course, this textbook should not have lacked a glossary. In particular, little attention is paid to high frequency words. So it should be taken with caution. If I used this textbook, I would first produce a list of high frequency words, and then adopt a star coding system to highlight them, including phonetic symbols and their meanings. In class, I would focus on teaching middle schools students how to pronounce a new word and explain its meaning using some example sentences.

\section{Conclusions}

Although it was published 25 years ago, this textbook for intensive reading still merits much attention. By analyzing its contents from the perspectives of reading and vocabulary theories, this study shows that the textbook 1) emphasizes the value of schema theory in reading comprehension; 2) trains students to properly use strategies in reading process; 3 ) takes into account the role of motivation in reading, and 4) stresses the vocabulary growth and grammar through reading. These four characteristics may serve as the important principles of choosing appropriate textbooks or reading materials for EFL teachers and learners. Moreover, this textbook can be used as a supplementary extensive reading material for middle school students who endeavour to enhance their reading proficiency level.

Nevertheless, it is not enough to evaluate a textbook from theoretical points of view. In the future study, a self-report questionnaire or an interview has to be conducted on materials users including teachers and students to explore its deeper pedagogical value. Further to this, a study on word frequency of the textbook is necessary to create a high frequency word list.

\section{Acknowledgements}

I would like to thank the Library of National Institute of Education, Nanyang Technological University, Singapore for providing the textbook under review, and the anonymous reviewers for their careful reading of the manuscript and their valuable feedback and comments. This work was financed by Projects of China Adult Education Association (Grant No.: 2017-064Y) and Foshan Federa- 
tion of Social Science Associations (Grant No.: 2020-GJ119).

\section{Conflicts of Interest}

The author declares no conflicts of interest regarding the publication of this paper.

\section{References}

[1] Murphy, D. and Janelle, C. (1995) Getting the Message: A Reading Course for Schools (Student's Book One). Cambridge University Press, Cambridge.

[2] Carrell, P.L. and Eisterhold, J.C. (1983) Schema Theory and ESL Reading Pedagogy. TESOL Quarterly, 17, 553-573. https://doi.org/10.2307/3586613

[3] Alptekin, C. (2006) Cultural Familiarity in Inferential and Literal Comprehension in L2 Reading. System, 34, 494-508. https://doi.org/10.1016/j.system.2006.05.003

[4] Hudson, T. (2007) Teaching Second Language Reading. Oxford University Press, Oxford.

[5] Sharp, A. (2004) Strategies and Predilections in Reading Expository Text: The Importance of Text Patterns. RELC Journal, 35, 329-349.

https://doi.org/10.1177/0033688205052145

[6] Pang, J. (2008) Research on Good and Poor Reader Characteristics: Implications for L2 Reading Research in China. Reading in a Foreign Language, 20, 1-18.

[7] Grabe, W. (2009) Reading in a Second Language: Moving from Theory to Practice. Cambridge University Press, Cambridge.

https://doi.org/10.1017/CBO9781139150484

[8] Cohen, A. (1984) Studying Second Language Learning Strategies: How Do We Get the Information. Applied Linguistics, 5, 101-111.

https://doi.org/10.1093/applin/5.2.101

[9] Griffiths, C. (2013) The Strategy Factor in Successful Language Learning. Multilingual Matters, Bristol. https://doi.org/10.21832/9781847699428

[10] O’Malley, J.M. and Chamot, A.U. (1990) Learning Strategies in Second Language Acquisition. Cambridge University Press, New York. https://doi.org/10.1017/CBO9781139524490

[11] Oxford, R.L. (1990) Language Learning Strategies: What Every Teacher Should Know. Heinle \& Heinle, Boston.

[12] Chamot, A.U. (2005) Language Learning Strategy Instruction: Current Issues and Research. Annual Review of Applied Linguistics, 25, 112-130. https://doi.org/10.1017/S0267190505000061

[13] Gambrell, L.B. (2011) Seven Rules of Engagement: What's Most Important to Know about Motivation to Read. The ReadingTeacher, 65, 172-178. https://doi.org/10.1002/TRTR.01024

[14] Laufer, B., Meara, P. and Nation, P. (2005) Ten Best Ideas for Teaching Vocabulary. The Language Teacher, 29, 3-6. 